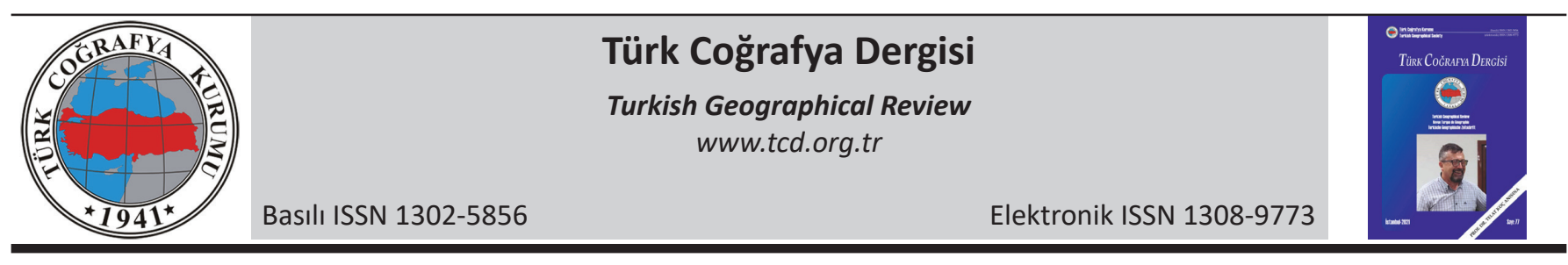

\title{
Antropo-jeomorfolojik bir yaklaşımla Bilecik (Merkez ilçe) taş ocaklarının mekânsal ve zamansal değişimi
}

\section{Spatiotemporal change of Bilecik (central district) quarries with an Anthropo-geomorphological approach}

\author{
Levent Uncu a (1) Ebubekir Karakoca *b \\ ${ }^{a}$ Bilecik Şeyh Edebali Üniversitesi, Fen Edebiyat Fakültesi, Coğrafya Bölümü, Bilecik, Türkiye. \\ ${ }^{b}$ Bilecik Şeyh Edebali Üniversitesi, Fen Edebiyat Fakültesi, Coğrafya Bölümü, Bilecik, Türkiye.
}

ORCID: L.U. 0000-0002-3908-1157; E.K. 0000-0002-6454-2082

\section{BILGI / INFO}

Geliş/Received: 06.05.2021

Kabul/Accepted: 27.05.2021

\section{Anahtar Kelimeler:}

Antroposen

Antropojenik jeomorfoloji

Bilecik

Taş ocakları

Mekânsal ve zamansal değişim

Keywords:

Anthropocene

Anthropogenic geomorphology

Bilecik

Quarries

Spatiotemporal change

*Sorumlu yazar/Corresponding author:

(E. Karakoca)

ebubekir.karakoca@bilecik.edu.tr

DOI: $10.17211 /$ tcd.933685

\section{Atff/Citation}

Uncu, L., \& Karakoca, E. (2021). Antropo-jeomorfolojik bir yaklaşımla Bilecik (Merkez ilçe) taş ocaklarının mekânsal ve zamansal değişimi. Türk Coğrafya Dergisi, (77), 119-130. https://doi.org/10.17211/tcd.933685

\begin{abstract}
ÖZ / ABSTRACT
Türkiye'de, son yıllarda artan hammadde ihtiyacı ve talep ile birlikte taş ocağı işletmelerinin sayısında hızı bir artş meydana gelmiştir. Bilecik gerek zengin rezervlere sahip olması gerekse ekonomisinin büyük ölçüde taşa-toprağa dayalı sanayiye bağı olması nedeniyle özellikle dikkat çekicidir. Bu çaış̧manın amacı, Bilecik merkez ilçe ve köylerindeki taş ocağı işletmelerinin mekânsal ve zamansal gelişimlerini antropo-jeomorfolojik bir yaklaşımla ortaya koymaktır. Çalışmada, Bilecik merkez ilçeye ait maden çıkarımı ve boşaltım verileri ile uydu görüntüleri kullanılmış, elde edilen bulgular arazi gözlemleri ile desteklenmiştir. Buna göre, Bilecik merkez ilçe ve köylerindeki taş ocaklarının zamansal ve mekânsal gelişiminde üç dönem (2003, 2013 ve 2016 yılları) ayırt edilmiştir. Bilecik'teki işletmelerin yol açtı̆ı sorunlar ise açma ve attk alanlarının topoğrafyada yarattı̆ı görüntü kirliliği, gürültü kirliliği, hava ve su kalitesinde bozulma, toprak kirliliği ve tarımsal verim düşüklüğü, biyo-çeşitlilikte azalma ve halk sağlığı üzerindeki olumsuz etkiler olarak belirtilebilir. Sonuç olarak, bu sorunların, sürdürülebilir kalkınma çerçevesinde çevresel değerlere uygun koşullara dönüştürülmesi amacıyla taş ocaklarında çeşitli çalışmalar yapılması gerekmektedir. Bu çalışmaların başında işletmelerin ciddi bir şekilde denetlenerek kontrol altına alınması gelmektedir. Ayrıca, eski işletmelerin rehabilite edilerek kamu yararına uygun bir şekilde rekreasyonel amaçılı faaliyetler için değerlendirilmesi de yerinde bir karar olacaktr.
\end{abstract}

In recent years, number of quarries in Turkey has rapidly increased due to growing demands on raw material. Province of Bilecik is particularly remarkable because it has rich reserves and its economy depends largely on the industry based on stone and soil. Adopting an anthropogenic geomorphological approach, this study aims to reveal spatial distribution and temporal changes of quarries in Bilecik. In the study, mine extraction and discharge data, satellite images of Bilecik central district were used, and the results were observed by field studies. Accordingly, three periods (2003, 2013 and 2016) were founded in the temporal and spatial development of the quarries in the central districts and villages of Bilecik. The problems which Bilecik quarries include visual pollution caused by mine trenches and waste areas in the topography, noise pollution, degradation in air and water quality, soil pollution, low productivity in agricultural activities, decrease in biodiversity and negative effects on human health. As a result, various regulations should be made in quarries in order to transform these negative effects into suitable conditions for environmental values within the framework of sustainable development. For this, quarries need to be seriously inspected and taken under control. In addition, it would be an appropriate decision to rehabilitate and enrich the old quarries for recreational activities for the public welfare.

\section{Extended Abstract Introduction}

Since the Industrial Revolution, due to the extremely increasing world population and advanced technology, huge changes have occurred in how people perceive and evaluate the natural environment they live in. With this period called the Anthropocene, human beings have begun to constantly transform and reshape the natural environment according to their needs and desires. Mines and quarries are the most common areas where the dimensions of the changes made by humans in the physical landscape and the problems they cause are most prominent.

In recent years, there has been a significant increase in the number of mines and quarries in Turkey in order to supply the raw material needs of the industry and the construction sector. Thanks to the richness of the raw material resources in 
Bilecik and the advantages of its proximity to big cities, the industry based on stone and soil has developed rapidly since the 2000s. In addition, there has been a serious explosion in the number of marble quarries as a sub-branch of the mining industry to meet the increasing demand of the construction industry. With an anthropo-geomorphological approach, this study aims to analyse spatiotemporal changes of the mines and quarries and offer solutions to the problems that arise with the changes in Bilecik.

In the anthropo-geomorphology approach, spatiotemporal differentiation and changes can be revealed in detail by assessing geomorphological (size and dimensions of anthropo-geomorphological processes), socio-economic (social and economic effects on human activities) and historical (changes in human influence over time) features.

\section{Purpose and Methodology}

In the study, 1: 25.000 and 1: 100.000 scaled topography and geology maps and 12,5 m resolution DEM data (ALOS GDSM-Advanced Land Observing Satellite-Global Digital Surface Model) were transferred to ArcMap 10.4 software and detailed maps (geology, digital elevation model, slope, river system) were produced. Satellite images and orthophotos were used in mapping the change of quarries in the context of time and space with the help of "mine extraction and discharge data of Bilecik central districts and villages" obtained from Bilecik Special Provincial Administration. In addition, the study was supported by field observations. Finally, Nir's (1983) "Potential Anthropogenic Geomorphology Index" was used to reveal the impact of anthropogenic effects on geomorphological processes and units in Bilecik and its surroundings.

\section{Findings and Discussion}

Due to the existence of geological and geomorphological features in Bilecik, the history of quarry and mining operations goes back to very old times. It is known that since ancient times, stone quarries and mining operations were very common around Bilecik and stone was sent as building material to many cities, especially Istanbul, during the Ottoman Period. However, a very rapid increase in the number of businesses in the province after the 2000s draws attention. As a result of the analysis of "Bilecik province mining and material storage data" obtained from Bilecik Special Provincial Administration, three periods covering the years 2003, 2013, and 2016 were found in the spatial and temporal change of the quarries and extraction areas in the central district of Bilecik.

In Bilecik central district, in 2003, mine extraction was made at 53 points in 17 villages, this number increased to 123 points in 28 villages in 2013 and 137 points in 30 villages in 2016. Accordingly, between 2003 and 2013, there was a 2.5-fold increase in the number of villages with new quarries and mine extraction points. On the other hand, between 2013 and 2016, mining started in only 2 new villages, and at 15 new points. The increase in the area of mine extraction is much more striking. In Bilecik's central districts and villages, the surface area of the mining extraction areas, which was 1.219,546 $\mathrm{m}^{2}$ in 2003, reached $3.251,458 \mathrm{~m}^{2}$ in 2013 and increased by 2.5 times in 2016 to $8.588,947 \mathrm{~m}^{2}$.
As can be seen, since the beginning of the 2000s, the mining areas in the central district of Bilecik has increased both numerically and spatially. Thus, many geomorphological units were either completely destroyed by excavations or degradation in a short time. In order to reveal the effects of anthropogenic activities in Bilecik on geomorphological units and processes, Nir's (1983) "Potential Anthropo-geomorphological Index" analysis was applied and in the anthropo-geomorphological process the ratio of the study area was determined as 0,45 . According to this index value, Bilecik central district is located in the "medium-scale" in the anthropogenic threat scale, but it is positioned at a point close to the high value and it seems possible to control the threats created by anthropogenic effects by taking some protection decisions and measures.

\section{Conclusion}

As revealed in the case of Bilecik and the central district, the quarries, which are considered within the mining enterprises, are of great importance for the economy of the country, and on the other hand, they threaten the local people and the ecosystem to a great extent with their effects on the physical landscape. Therefore, mining activities and quarry operations should be carried out within the framework of sustainable development. Common complaints of local people living near these businesses are that visual pollution in the topography caused by areas opened and improperly managed wastes, noise pollution caused by explosions in the quarries, serious health problems due to the decrease in air quality due to dust, pollution in surface and groundwater, agricultural land becoming unusable, complete removal of natural vegetation, or destruction and decrease in biodiversity. Indeed, the complaints of the local people can be reduced or resolved with the precautions to be taken and the strict supervision to be made.

As a result, various regulations should be carried out in quarries in order to transform these negative effects into conditions suitable for environmental values within the framework of sustainable development. For this, it is necessary to control whether the existing quarries are working in accordance with the license and the unplanned quarries should be taken under control. In addition, it would be an appropriate decision to enrich the old quarries for recreational activities in accordance with the public interest.

\section{Giriş}

İnsan ortaya çıkışını takip eden dönemde, biyolojik ve kültürel gelişimine de bağlı olarak, uzun süre doğayla uyumlu bir şekilde yaşadığı için doğal ortam üzerindeki etkileri de sınırlı ve küçük ölçekli kalmıştır. Bununla birlikte, özellikle Sanayi devriminden sonra, hızla artmaya başlayan dünya nüfusu ve gelişen teknolojik imkanlara bağlı olarak, insanın yaşadığı doğal ortamı algılama ve değerlendirme biçiminde büyük değişiklikler meydana gelmiştir. Bu süreçle birlikte, insan yaşadığı doğal ortamı ihtiyaç ve istekleri doğrultusunda değiştirmeye ve yeniden şekillendirmeye başlamıştır. İnsanlar günümüzde teknolojinin sağladığı imkanları kullanarak, yeni yerleşme yerleri açmak, altyapı çalışmaları yapmak, ekonomik amaçlı tesisler (fabrikalar, rafineriler, organize sanayi bölgeleri) kurmak, ulaşım ağı sistemleri (otoyollar, havalimanları, limanlar, tüneller) ve hidrolik tesisler (sulama kanalları ve barajlar) inşa 
etmek, sanayinin hammadde ihtiyacını karşılamak (maden ve taş ocakları) ve yeni tarım alanları (plantasyonlar, seralar) oluşturmak için fiziki peyzaj üzerinde büyük ölçekli değişiklikler yapmaktadır (Şekil 1).

İnsanın fiziki peyzajda yapmış olduğu değişiklerin boyutları ve yarattı̆ı sorunlar, özellikle 20. yy.'ın ikinci yarısından itibaren birçok araştırmacının dikkatini çekmiştir. İlk defa, 21. yy.ın başlarında Sanayi Devrimi'nden günümüze kadar gelişen dönemin "Antroposen-İnsan Çağı" olarak adlandırılması görüşü ileri sürülmüş (Crutzen \& Stoermer, 2000; Crutzen, 2002) ve doğa bilimlerinin farklı disiplinleri içerisinde büyük tartı̧̧malara yol açmıştır. Bu tartş̧malar çoğunlukla, Antroposen'in başlangıcını işaret eden altın bir zirvenin (Sanayi Devrimi veya 1950'lerdeki "Büyük İvme - The Great Acceleration") var olup olmadığı ve kavramın jeolojik terminolojide gerekliliği konusuna odaklanmıştır (Steffen vd., 2007, 2011; Szabo, 2010; Zalasiewicz vd., 2010, 2011; Goudie \& Viles, 2016). 2016 yılında, Antroposen'in dünya tarihinde, "doğal güçlerle insani güçlerin birbirlerinin kaderini belirleyecek şekilde iç içe geçtiği yeni bir aşamayı temsil ettiği" yönündeki görüş ağır basmış ve Antroposen'in Holosen'den ayrı bir jeolojik çağ olarak değerlendirilmesi önerilmiştir (Steffen vd., 2016; Zalasiewicz vd., 2019).

Başlangıç zamanı farklılıklar göstermekle birlikte, araştırmacıların kabul ettiği ortak özellik Antroposen'de dünya sistemini oluşturan litosfer, atmosfer, hidrosfer, biyosfer ve kriyosfer üzerinde insan etkisinin muazzam bir şekilde arttğı ve insanın doğal süreçlerin ve dinamiklerin baskın bir parçası olduğu yönündedir. Bu durum, başta coğrafya olmak üzere doğal ortam-insan ilişkisi konusunda çalışan bilim dallarında antropojenik temelli bir bakış açısının ortaya çıkmasını sağlamıştır. Bu çalışma alanları arasında, jeomorfolojinin bir alt dalı olarak ortaya çıkan "Antropo-jeomorfoloji" veya "Antropojenik jeomorfoloji" özellikle dikkat çekmektedir (Ertek, 2017).

"Antropo-jeomorfoloji" terimi ilk defa Golomb \& Eder (1964) tarafindan "yer şekillerinin oluşumunda ve jeomorfolojik süreçlerin işleyişinde insanın rolünün incelenmesi" olarak önerilmiştir. Szabo (2010) ise "antropojenik jeomorfoloji" terimini "konusu, kökeni ve amacı son derece farklı insan topluluklarının etkinlikleri tarafindan yaratılmış olan, sürekli gelişen ve genişleyen insan yapımı yeni yerşekillerini" tanımlamak için kullanmıştır. Görüldüğü üzere, her iki terimde, kapsadığı dönem itibariyle Antroposen'de jeomorfolojik birimler ve süreçlerin işleyişi üzerine insanın yapmış olduğu doğrudan ve dolaylı etkilere odaklanmaktadır.

Antropojenik jeomorfoloji gerçekte, yerkürenin dinamik karasal yüzeyini kaplayan jeomorfolojik katmanların sadece bir tabakasını oluşturmaktadır (Tarolli \& Sofia, 2016; Ellis vd., 2018; Tarolli vd. 2019). Bu nedenle, Dünya genelinde ve zaman boyutunda antropojenik jeomorfolojinin sistematik bir değerlendirilmesinin yapılabilmesi için, farklı yaklaşımların bir araya getirilerek genel bir çerçeve sunulması ve toplumların jeomorfolojik nişlerinin belirlenmesi gerekmektedir (Rózsa, 2007). Antropojenik jeomorfolojideki yaklaşımlar; jeomorfolojik, sosyo-ekonomik ve tarihsel olmak üzere üç başlık altında toplanabilir. Jeomorfolojik yaklaşım, antropo-jeomorfolojik süreçlerin büyüklüğü ve boyutlarını, sosyo-ekonomik yaklaşım insan etkinliklerinin sosyal ve ekonomik etkilerini, tarihsel yaklaşım ise, jeomorfolojik süreçler üzerindeki insan etkisinin zaman içindeki değişimini incelemektedir. Bu yaklaşımların birlikte değerlendirilmesi sonucunda ise antropo-jeomorfolojik etkinliklerin mekânsal ve zamansal farklılaşması detaylı bir şekilde ortaya konulabilmektedir.

Afrika'da yapılan son araştırmalar, insanın doğadan faydalanmaya yönelik girişimlerinin 3,3 milyon yıl önce (Homininler) ilk taş aletlerin yapılmasıyla birlikte başladığını göstermektedir (Harmand vd. 2015). Zamanla alet yapma becerisindeki ilerlemelere bağlı olarak doğal taşlar (özellikle çakmaktaşı ve obsidiyen), insanın kültürel gelişiminde üç dönemin ayırt edilmesine imkân sağlamıştır. Bu dönemlerden Paleolitik ve Mezolitik (Epipaleolitik) sırasında avlanma ve kesme amaçlı alet yapımında kullanılan taş, Neolitik Dönem'de tarımın başlaması ve yerleşik hayata geçiş ile birlikte değer kazanarak ticari bir meta olarak kullanılmaya başlamıştır. Kalkolitik Dönem'de insan madeni kullanmaya başlamış ve önce bakır, daha sonra ise kalay, demir gibi madenleri işleyerek kültürel gelişiminde önemli aşamalar kat etmiştir. Özellikle, köylerin kentlere doğru evrilmesi süreci, kerpiç ve ahşaba göre daha dayanıklı ve sağlam bir yapı malzemesi olan taşa duyulan intiyaç artmıştr. Antik dönem sırasında ise komplike kentlerin ve kültürel yapıların inşa edilmese başlamasıyla birlikte birçok antik kentin çevresinde taş ocakları işletilmeye başlamıştir. Efes, Milet, Pergamon, Troia gibi dünyaca meşhur antik kentlerdeki intişamlı yapılarda bu ocaklardan elde edilen doğal taşlar kullanılmıştır. Doğal taşların yanı sıra, bazı değerli ve yarı değerli taşlar da çok erken dönemlerden itibaren takı yapımında kullanılmış ve ticarete konu olmuştur (Şekil 1).

Tarihi kaynaklarda, antik dönemin yanı sıra Bizans ve Osmanlı Dönemi'nde de silah yapımı ve anıtsal yapıların inşasında kullanılmak üzere, Anadolu'nun pek çok yerindeki maden ve taş ocaklarından malzeme getirildiğine dair bilgiler bulunmaktadır. Buna göre, Türkiye'de çok erken dönemlerden beri işletilen maden ve taş ocaklarının yaygın olması hem kazılmalar yoluyla doğrudan hem de yararsız yığınlar ve subsidans yoluyla dolaylı olarak antropojenik kökenli yer şekillerinin oluşumunda etkili olmuştur (Erkal \& Taş, 2013).

Türkiye genelinde, özellikle son yıllarda, gerek taşa-toprağa dayalı sanayinin gerekse inşaat sektörünün hammadde ihtiyacını karşılamak üzere açılan maden ve taş ocaklarının sayısındaki artş̧, antropojenik kökenli yer şekillerinin oluşumunu daha da hızlandırmıştır. Bu durumun en dikkat çeken örneklerinden birini de hiç kuşkusuz Bilecik ili oluşturmaktadır. Bilecik ili, taşa-toprağa dayalı sanayinin ihtiyaç duyduğu metal (asbest, manganez, krom, volfram gibi) ve metal olmayan madenler (kil, kaolen, feldspat, kuvars, mermer gibi) bakımından zengin rezervlere sahiptir. Gerek hammadde kaynaklarının çeşitliliği ve rezervlerinin zenginliği gerekse büyük şehirlere yakınlığının sağladığı avantaj (İstanbul, Bursa, Eskişehir başta olmak üzere) nedeniyle Bilecik ilinde özellikle son 20 yılda taşa-toprağa dayalı sanayi ve ona bağlı yan kollar hızlı bir gelişme göstermiştir. Aynı süreçte, inşaat sektöründe artan yerli ve uluslararası talebe de bağlı olarak, ildeki taş ocaklarının sayısında da büyük bir artış yaşanmıştır.

Türkiye'de madenlerle ilgili çok sayıda düzenlemeyi içeren ilk kapsamlı yasa olan ve 4.6.1985 tarihinde yürürlüğe giren 3213 sayılı Maden Yasası'na göre, "ticari standartlara uygun boyutlarda blok verebilen, kesilip parlatılan veya yüzeyi işlenebilen ve taş özellikleri kaplama taşı normlarına uygun olan her türden 


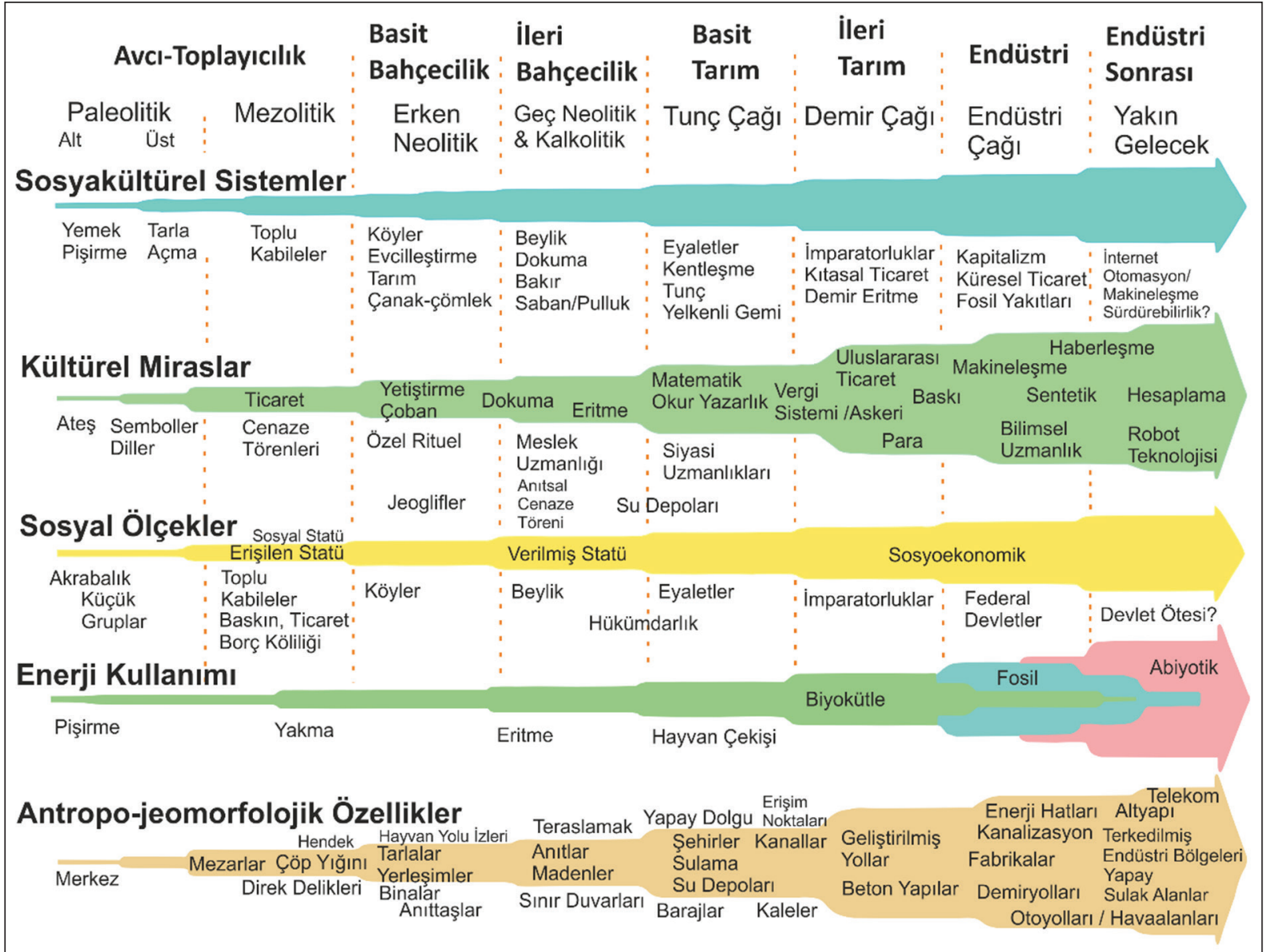

Şekil 1. İnsanlığın kültürel tarihi boyunca, sosyo-kültürel sistemler, kültürel miraslar, toplumsal ölçekler, enerji kullanımı ve antropo-jeomorfolojik özelliklerde meydana gelen değişimleri gösteren kavramsal diyagram (Tarolli vd., 2019'dan değiştirilmiştir).

Figure 1. The conceptual diagram showing the changes in socio-cultural systems, cultural heritages, social scales, energy use and anthropo geomorphological characteristics throughout the cultural history of humanity (Changed from Tarolli et al., 2019).

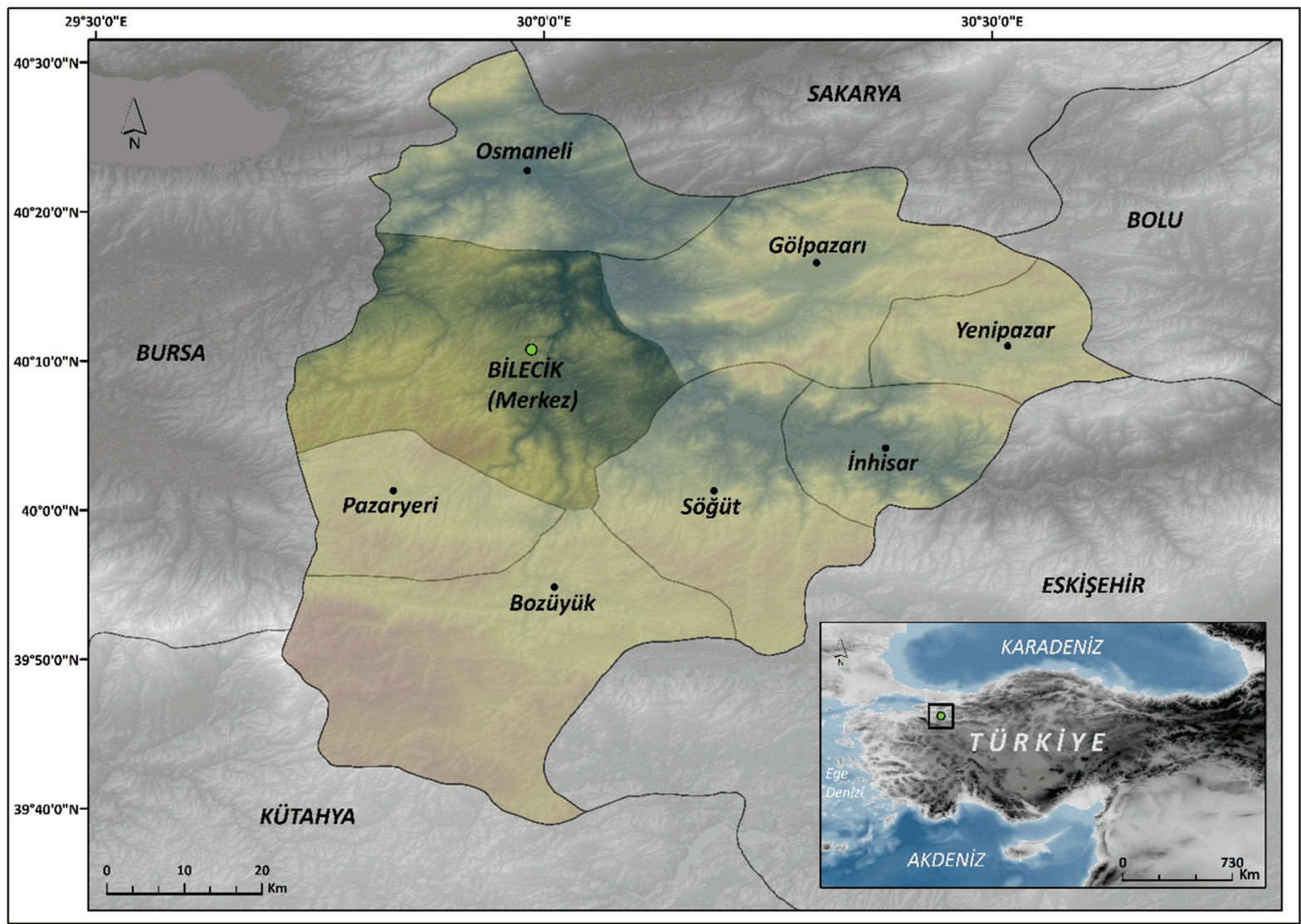

Şekil 2. Çalışma sahasının lokasyon haritası.

Figure 2. Location map of the study area. 
taş (tortul, magmatik, metamorfik) ticari bakımdan "mermer" olarak adlandırılmıştır. Bu tanımlamanın içerisinde, bilimsel olarak metamorfik bir kayaç olan gerçek mermerin yanı sıra iyi parlatılabilen kireçtaşı, traverten, kumtaşı gibi tortul kayaçlar, granit, andezit, bazalt gibi magmatik kayaçlar ve metamorfik kayaçlardan gnays, kuvarsit ve serpantinler de bulunmaktadır.

Son olarak, 21.09.2017 tarih ve 30187 sayılı Resmî Gazete'de yayınlanarak yürürlüğe giren Maden Yönetmeliği'ne göre ise madenler 5 gruba ayrılarak ruhsatlandırılmaktadır. Buna göre taş ocağı işletmeleri, a) yapı taşları, hazır beton ve asfalt üretiminde kullanılan kayaçlar, b) dekoratif amaçı kullanılan doğal taşlar, c) hammadde olarak kullanılan kayaçlar olarak üç madde halinde "II. Grup madenler" içerisinde değerlendirilmiştir (Orhan \& Arık, 2019). Bilecik ilinde, "II. Grup maden" içerisinde değerlendirilen taş türlerinin hemen hepsi yaygın olarak bulunmakta ve bunlar "mermer ocağı" olarak ruhsatlandırılarak "maden açma”ları olarak işletilmektedir. Bu çalışmada, antropo-jeomorfolojik bir yaklaşımla, Bilecik merkez ilçe ve köylerindeki maden açmalarının mekânsal ve zamansal değişimi, işletmelerin yol açtı̆̆ sorunlar ve bu sorunlar dair çözüm önerilerinin ortaya konulması amaçlanmıştır.

Bilecik merkez ilçe, Marmara Bölgesi'nin Güneydoğu Marmara Bölümü'nde, $40^{\circ} 00^{\prime} 00^{\prime \prime}-40^{\circ} 20^{\prime} 00^{\prime \prime}$ kuzey enlemleri ile $29^{\circ} 40$ $00^{\prime \prime}-30^{\circ} 10^{\prime} 00^{\prime \prime}$ doğu boylamları arasında bulunmaktadır. Saha, batıdan Bursa iline bağlı İnegöl ilçesi, doğudan Pazaryeri ve Bozüyük ilçeleri, güneyden Söğüt ve Gölpazarı ilçeleri ile kuzeyden ise Osmaneli ilçesi sınırlandırılmaktadır (Şekil 2). Toplam yüzölçümü 793 km² olan Bilecik merkez ilçenin nüfusu ise Türkiye İstatistik Kurumu'nun 2020 yılı verilerine göre 78.029 kişidir.

\section{Veri ve Yöntem}

Çalışmanın ilk aşamasında 1:25.000 ve 1:100.000 ölçekli topografya (Harita Genel Komutanlığı) ve jeoloji haritaları (MTA) ile birlikte 12,5 m çözünürlüklü DEM (ALOS GDSM-Advanced Land Observing Satellite-Global Digital Surface Model) verileri ArcMap 10.4 yazılımına aktarılarak sahanın detaylı haritaları (jeoloji, sayısal yükseklik modeli, eğim, akarsu ağı gibi) üretilmiştir. Uydu (2003, 2013, 2016 yıllarına ait) ve ortofoto görüntüleri (2019 yılına ait) ise Bilecik İ Özel İdaresi'nden temin edilen "Bilecik merkez ilçe ve köylerine ait maden çıkarımı ve boşaltım verileri" ile birlikte taş ocaklarının zaman ve mekân bağlamında değişiminin haritalanmasında kullanılmıştır. Bunun yanı sıra çalışma, arazi gözlemleri ile desteklenmiştir.

Son olarak, Bilecik ve çevresinde antropojenik kökenli faaliyetlerin jeomorfolojik süreç ve birimler üzerinde etkisini ortaya koyabilmek amacıyla Nir (1983) tarafindan hazırlanan "Potansiyel Antropojenik Jeomorfoloji İndeksi" kullanılmıştır. Nir'in indeksi "gelişme derecesi" ve "algılama derecesi" olmak üzere iki parametreye dayanmaktadır. Bu parametrelerden ilki insan etkisinin oranını yansıtırken, ikincisi antropo-jeomorfolojik süreçlerden kaynaklanan tehdit algısı ile ilgilidir.

Nir (1983)'in "Potansiyel Antropojenik Jeomorfoloji İndeksi" formülü şöyledir:

$\mathrm{I}=\mathrm{UP}+\mathrm{DI} / 2 \times 1 / 100 \times(\mathrm{Kc}+\mathrm{Kr})$

Formülde; (I) Potansiyel Antropojenik Jeomorfoloji indeksini, (UP) kentsel nüfusun oranını, (DI) okuma yazma bilmeyenlerin oranını, (Kc) iklim tipini (Köppen-Geiger iklim sınıflandırmasına göre) ve ( $\mathrm{Kr}$ ) rölyef değerlerini göstermektedir (Tablo 1 ).

Formülün uygulanması ve sonucun yorumlanması süreci ise indeks değerinin yer aldığı aralık ile ilişkili olarak "Antropojenik Jeomorfoloji Süreç İndeksi" tehdit skalası değerlerini (0-0,25: düşük; 0,25-0,50: orta; 0,50-0,75: yüksek; 0,75-1: çok yüksek) kapsamaktadır. Buna göre, indeks değerinin, 0,25'ten küçük olması sahadaki antropojenik faaliyetlerin etki boyutu düşük bir tehdit oluşturduğunu, 0,25-0,50 arasında olması tehdidin önemsiz olmadığını ve bazı koruma önlemleriyle kontrol altına alınabileceğini, 0,50'den büyük olması ise antropojenik faaliyetlerin yüksek oranda sorun oluşturduğunu ve acil önlemlerin alınması gerektiğini göstermektedir.

Formülde ihtiyaç duyulan iklim ve rölyef değerleri için, Nir (1983)'in standart değerleri esas alınmıştır (Tablo 1). Köppen-Geiger iklim sınıflandırmasına göre Bilecik, "Akdeniz iklimine karşılık gelen, kışları ılık, yazları çok sıcak olan orta enlem iklim tipi (Csa)" olarak tespit edilmiştir (Öztürk vd., 2017). Bu nedenle, formüldeki iklim (Kc) değeri, 0,4 olarak belirlenmiştir. Çalışma sahasının jeomorfolojik ve morfometrik özellikleri bakımından plato karakterinde olmasından dolayı rölyef $(\mathrm{Kr})$ değeri ise 0,5 olarak alınmıştır. Türkiye İstatistik Kurumu (TUIK) verilerine göre ise formüldeki kentsel nüfusun oranı \%100, okuma yazma bilmeyenlerin oranı ise \%1,9 olarak kabul edilmiştir.

Tablo 1. Potansiyel antropojenik jeomorfoloji indeksinde kullanılacak iklim ve rölyef değerleri (Nir, 1983).

Table 1. Climate and relief values to be used in the potential anthropogenic geomorphology index (Nir, 1983).

\begin{tabular}{|c|c|c|c|}
\hline İklim Değerleri (Kc) & Değer & Rölyef Değerleri (Kr) & Değer \\
\hline Ekvatoral İklim (Ae) & 0,6 & Ovalar & 0,2 \\
\hline Muson-Savan İklimi (Aw) & 0,8 & Tepeler & 0,4 \\
\hline Kurak ve Yarı Kurak İklim (B) & 0,6 & Platolar & 0,5 \\
\hline Ilıman İklim (C) & 0,4 & Orta-Yüksek Dağlık Alanlar & 0,6 \\
\hline Soğuk İklim (D) & 0,6 & Yüksek Dağlık Alanlar & 0,8 \\
\hline Kutup İklimi (E) & 0,4 & & \\
\hline
\end{tabular}

\section{Bulgular}

\section{1. Çalışma Alanının Jeolojik ve Jeomorfolojik Özellikleri}

Maden ve taş ocaklarının açılışında en önemli rolü, kuşkusuz sahanın jeolojik (litoloji ve tektonik) ve jeomorfolojik özellikleri oynamaktadır. Bilecik çevresinde, taş ocağı işletmelerinin özellikle tercih ettiği karbonatlı birimler geniş alanlarda yüzlekler vermektedir (Şekil 3). Bölgenin temelini oluşturan Paleozoik yaşı kristalin şistleri örten sarı-yeşil renkli kumtaşları ve konglomeraların üzerine gelen bu birimler, Orta Jura-Alt Kretase yaşlı kireçtaşları (Bilecik formasyonu) ile Üst Kretase yaşlı killi kireçtaşlarından (Yenipazar formasyonu) oluşmaktadır. Mesozoik sırasında bölgede hâkim olan denizlerdeki sığ platformlarda biriktirilmiş olan karbonatlı birimler, alt kısmında krem renkli kireçtaşlarıyla başlar ve yukarıya doğru önce kırmızı renkli plaketli kireçtaşlarına daha sonra ise beyaz renkli killi kireçtaşlarına geçer (Sayar \& Erguvanlı, 1962). Karbonatlı birimler, çoğu yerde kalınlığı 15-60 cm arasında değişen kesilmeye uygun kireçtaşı plakaları oluşturmakta veya metamorfizmaya uğradığı kesimlerde rekristalize kireçtaşı veya mermer özelliği kazanarak som bir doku göstermektedir. Birimin içerisindeki kırık ve çatlakları dolduran beyaz veya kırmızı renkli kalsit da- 
marları ise birimin yer yer "tektonik breş" özelliği kazanmasına yol açmıştır. Bu nedenle, Bilecik çevresinde, renk, yapı ve görünümleri itibarıyla farklılıklar göster taşlar piyasada çıkarıldıkları köy veya mevkiinin adıyla (Vezirhan, Taşçılar, Hırtılar, Gülümbe taşı gibi) tanınmaktadır (Sayar \& Erguvanlı, 1962).

Araştırma sahasındaki taş ocağı işletmeleri ile jeomorfolojik özellikler arasında da sıkı bir ilişki bulunmaktadır (Şekil 4). Bilecik çevresi, Sakarya Nehri'ne dökülen Karasu ve kolları tarafindan dik ve derin vadilerle yarılmış, üzerinde tepelerin yükseldiği engebeli bir plato özelliği göstermektedir (Karakoca \& Uncu, 2020). Sahadaki taş ocakları, jeolojik yapı ile uyumlu olarak, bu plato yüzeyinin kuzeydoğusunda ve eğim değerlerinin 30 dereceyi aşthğı sırtlar ve tepelik alanların yamaçlarında yoğunlaşmaktadır (Şekil 4). Bunun dışında taş ocağı işletmesi için tercih edilen diğer sahaları ise, plato üzerinde karbonatlı birimlerin diğer birimlerle kontakt halinde bulunduğu sahalardaki faylı yamaçlar oluşturmaktadır. Bununla birlikte, topografik koşullara bağlı olarak, Bilecik merkez ilçe ve köylerindeki taş ocaklarının birbirine çok yakın noktalarda açıldığı ve açık taş ocağı işletmeleri şeklinde arazide yatay bir yayılım gösterdiği dikkati çekmektedir. Bu durum, jeomorfolojik birimlerin önce tahrip edilmesine ilerleyen zamanda ise tamamen ortadan kaldırılmasına yol açmaktadır.

Taş ocağı işletmeciliği, resmi olarak, madencilik faaliyetlerinin bir alt kolu olarak kabul edilmekle birlikte, maden çıkarımından farklı olarak daha çok açık işletmeler şeklinde yürütülmektedir. Bu nedenle, maden çıkarımı faaliyetlerine göre arazide geniş alanlarında büyük boyutlu değişikliklere yol açmaktadır. Taş ocağı işletmelerinin arazideki jeomorfolojik birimler üzerine etkileri (a) kazılma, (b) yığılma ve (c) tahrip etme olarak üç grupta toplanabilir (David, 2008). Taş ocaklarının bulunduğu açık işletme sahalarında, jeomorfolojik birimler bir yandan malzeme alımı için kazılarak ve kesilerek dikey olarak alçalttlırken diğer yandan arazi yatay olarak düzleştirilmektedir. Bu işlemler sırasında açığa çıkan atık ve hafriyat malzemeleri ise kazılan sahanın hemen yakınında biriktirilmektedir. Bu durum, arazide doğal olmayan aşınım ve birikim süreçlerine bağlı olarak antropojenik kökenli “jeomorfolojik düzleşme yüzeyleri”nin oluşmasına yol açmaktadır (David, 2010). Bunun dışında, bazı ocakların ekonomik bakımdan rantabl bulunmayarak terk edilmesi sonucunda ise yerşekilleri tahrip edilerek bırakılmaktadır.

\subsection{Bilecik Merkez İlçedeki Taş Ocakları}

Bilecik merkez ilçe ve köylerindeki taş ocakları, litolojik olarak, kireçtaşı ve killi kireçtaşları gibi tortul kayaçların yaygın olduğu sahalarda bulunmakla birlikte, ticari olarak "mermer ocağı" olarak adlandırılmakta ve "II. Grup madenler" içerisinde ruhsatlandırılmaktadır. Bilecik'te üretilen mermerler, daha çok inşaat sektöründe dekorasyon amaçlı olarak kullanılmaktadır. Özellikle "Bilecik beji ve Bilecik gülkurusu" (toplam rezervi 406.000.000 $\mathrm{m}^{3}$ ) adıyla tanınan mermerler yerli ve uluslararası pazarlarda yoğun ilgi görmekte ve talep edilmektedir. Nitekim, 2015 yılında Bilecik'te üretilen mermerlerin \%25'i $\left(545.530 \mathrm{~m}^{2}\right.$ ) blok ve işlenmiş mermer olarak Çin, Hindistan, ABD, Birleşik Arap Emirlikleri ve Avrupa ülkelerine ihraç edilmiştir (BEBKA, 2017). Geri kalan kısmı ise, başta İstanbul, Bursa, Ankara, Eskişehir gibi büyük kentler olmak üzere yurtiçindeki çeşitli pazarlara gönderilmiştir.

Bilecik ili, Türkiye'de toplam mermer rezervleri bakımından 4. sırada bulunmakla birlikte yüzölçümüyle kıyaslandığında 1 . sırada yer almaktadır. 2017 yılında BEBKA (Bursa-Eskişehir-Bi-

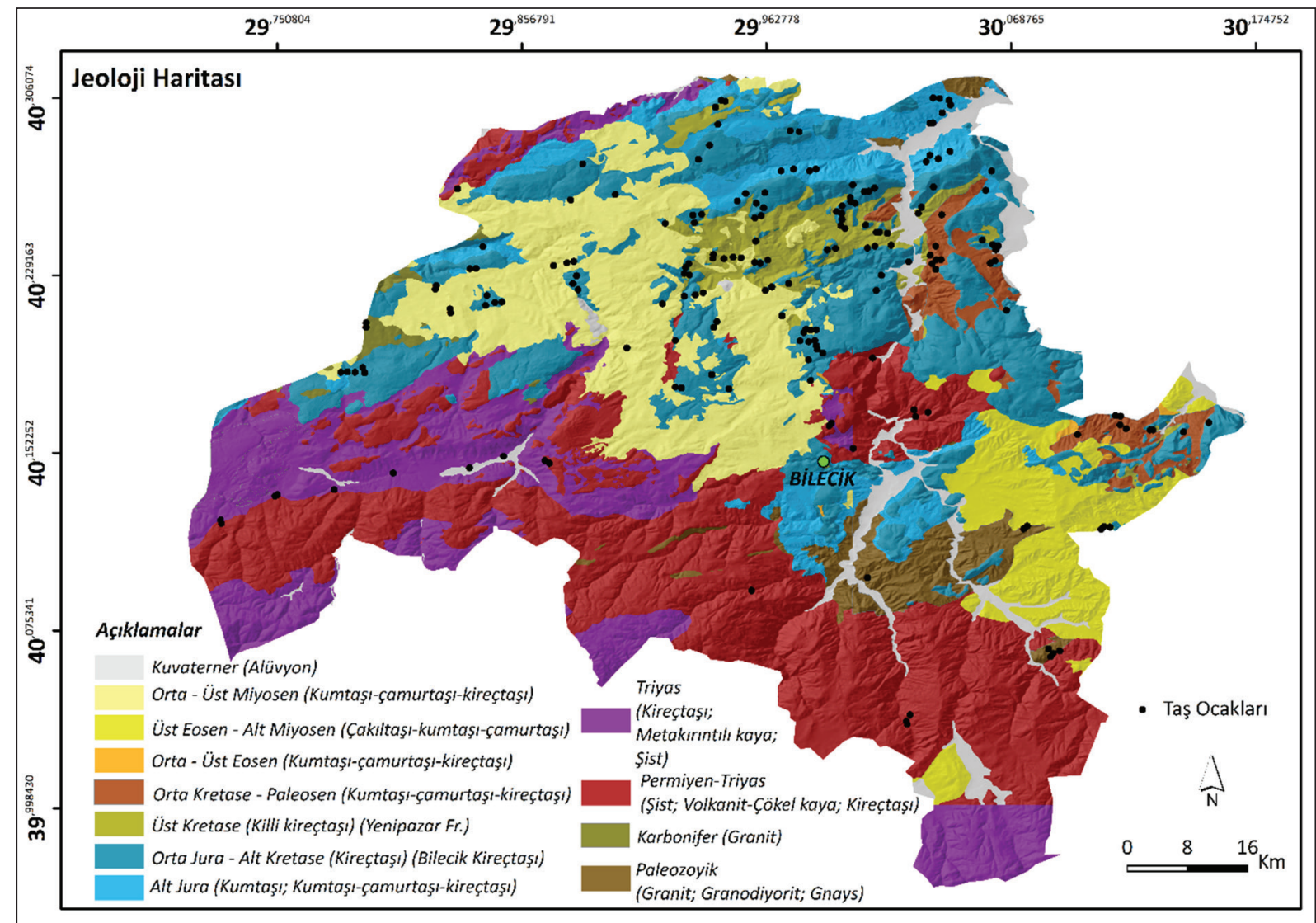

Şekil 3. Çalışma sahası içerisinde yer alan taş ocaklarının mekânsal dağılışı ile dağılışa etki eden jeolojik özellikler. Figure 3. Spatial distribution of the quarries in the study area and geological features that affect the distribution. 


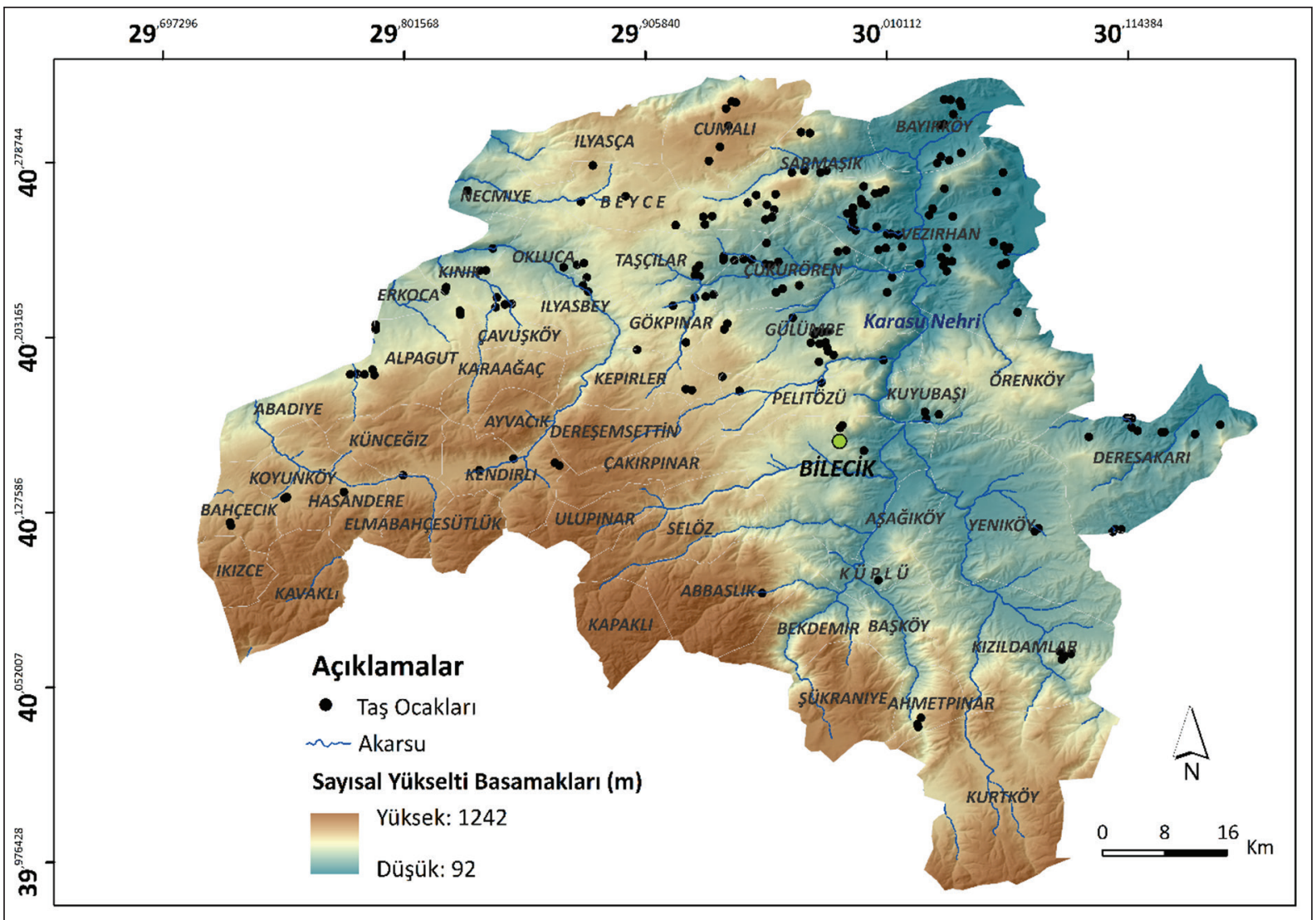

Şekil 4. Çalışma sahası içerisinde yer alan taş ocaklarının mekânsal dağılışı ile dağılışa etki eden jeomorfolojik özellikler. Figure 4. Spatial distribution of the quarries in the study area and geomorphological features that affect the distribution.

lecik Kalkınma Ajansı) tarafindan hazırlamış olan “Bilecik Mermer Sektörü Raporu”na göre, Bilecik'teki toplam 47 mermer ocağının 22 tanesi, 41 mermer fabrikasının ise 22 tanesi Merkez ilçede bulunmaktadır (Tablo 2).

Tablo 2. Bilecik'te mermer işletmelerinin coğrafi dağılışı.

Table 2. Geographical distribution of marble managements in Bilecik.

\begin{tabular}{|l|c|c|c|}
\hline İlçeler & $\begin{array}{c}\text { Mermer Ocağı } \\
\text { Sayısı }\end{array}$ & Fabrika Sayısı & $\begin{array}{c}\text { Toplam Mermer } \\
\text { İşletmesi Sayısı }\end{array}$ \\
\hline Bilecik Merkez & 22 & 22 & 44 \\
\hline Bozüyük & 1 & 4 & 5 \\
\hline Osmaneli & 2 & 9 & 11 \\
\hline İnhisar & 3 & 1 & 4 \\
\hline Gölpazarı & 8 & 1 & 9 \\
\hline Söğüt & 5 & 4 & 9 \\
\hline Yenipazar & 5 & - & 1 \\
\hline Pazaryeri & 1 & - & 88 \\
\hline Toplam & 47 & 41 & \\
\hline
\end{tabular}

Kaynak. Bilecik mermer sektörü raporu (BEBKA, 2017).

Bilecik'te taş ocağı ve maden işletmeciliğinin tarihi çok erken dönemlere gitmektedir. Antik dönemden beri, Bilecik çevresinde taş ocağı ve maden işletmelerinin çok yaygın olduğu ve Osmanlı Dönemi'nde İstanbul başta olmak üzere birçok şehre yapı malzemesi olarak taş gönderildiği bilinmektedir. Zaman içerisinde çoğu terk edilen bu ocaklar, özellikle 1950'li yıllardan itibaren İstanbul Üniversitesi öğretim üyelerinin bölgede yaptı̆̆ jeolojik etüdlerle birlikte yeniden önem kazanmaya başlamıştır. Bu yıllarda halen işletilmekte olan Hasandere ve Abbaslık köyü yakınlarındaki taş ocaklarından çıkartılan yeşil renkli serpantinler Anıtkabir'in iç dekorasyonunda kullanılmış$\operatorname{tr}$ (Sayar \& Erguvanlı, 1962). 1970'li yıllara Bilecik bir tarım kasabası özelliği göstermiş, sanayi yatırımı yapılmadığı için büyük ölçüde dışarıya göç vermek zorunda kalmıştr. Nihayet 1973 yılında, Bilecik'in "kalkınmada öncelikli yöreler" kapsamına alınmasından sonra hammaddesi taşa-toprağa dayalı ilk büyük fabrika olan Porland Porselen Fabrikası (1976) kurulmuştur. Bununla birlikte, Bilecik'te taşa-toprağa dayalı sanayi ancak 2000'li yıllardan itibaren ivme kazanmaya başlamıştır. 2003 yılında, Devlet Planlama Teşkilatının çeşitli sosyo-ekonomik değişkenlere göre yapmış olduğu "gelişmişlik" sıralamasında Bilecik, Türkiye'de 18. sırada yer almıştır. 2000 'li yıllardan itibaren artan yatırım ve teşviklerle birlikte, Bilecik merkez ilçede Bien Seramik (2006) ve ÇiMSA Çimento Fabrikası (2008) gibi büyük sanayi tesisleri kurulmuştur. Böylece, bu tesislerden çimento fabrikasının hammadde ihtiyacını karşılamak amacıyla, özellikle 2008 yılından sonra, merkez ilçe çevresindeki taş ocaklarının sayısı katlanarak artmıştır. Günümüzde, seramik ve porselen üretilen bu tesisler ve mermer ocakları hem yöre halkı için önemli bir istihdam alanı oluşturmakta hem de yerli ve uluslararası piyasada ticarete konu olmaktadır.

Gerçekte, Bilecik'teki maden işletmelerinden çıkartılan doğal taşlar arasında mermer sınırlı miktarda olmakla birlikte, "ticari" manada bütün taş ocakları "mermer ocağı" olarak kabul edilmekte ve ruhsatlandırılmaktadır. Bu nedenle, Bilecik il Özel İdaresi'nden alınan "Bilecik ili maden açma ve malzeme depolama verileri" değerlendirilirken, Merkez ilçe ve köylerinde maden çıkarımı yapılmadığı göz önünde bulundurularak tüm maden işletmeleri "taş ocağı" olarak değerlendirilmiştir. Bu değerlendirmeler sonucunda, son 20 yıl içerisinde, Bilecik merkez ilçedeki taş ocaklarının mekânsal ve zamansal değişiminde; 2003, 2013, 2016 yıllarına karşılık gelen üç dönem ayırt edilmiştir (Tablo 3). 
Özellikle, 2000'li yıllardan önce, Bilecik merkez ilçe ve köylerinde taş ocağı işletmeciliği sınırlı alanlarda ve küçük ölçekli olarak yapılmaktaydı. 2003 yıında, Merkez ilçeye bağlı toplam 17 köyde ve 53 noktada taş ocağı bulunuyordu. Bu işletmelerin sayısı 2013 yılında 28 köyde, 123 noktaya, 2016 yılında ise 30 köyde 137 noktaya çıkmıştır. Buna göre, 2003-2013 yılları arasında yeni ocak açılan köylerin ve maden çıkarım noktalarının sayısında 2,5 kat bir artş olmuştur. Buna karşın 2013-2016 yılları arasında ise sadece 2 yeni köyde ve 15 yeni noktada maden çıkarımı yapılmaya başlamıştır.

Aynı zaman dilimlerinde, maden çıkarım alanlarının yüzölçümündeki artı̧̧ ise çok daha dikkat çekicidir (Tablo 3). Bilecik merkez ilçe ve köylerinde, 2003 yılında 1.219,546 m² olan maden çıkarım alanlarının yüzölçümü, 2013 yılında 3.251,458 m²'ye, 2016 yılında ise 2,5 kat kadar artarak 8.588,947 m²'ye ulaşmıştır.

Tablo 3'de görüldüğü üzere, Bilecik merkez ilçede, taş ocağı işletmelerinin alansal olarak en geniş alan kapladığı yerleşme Vezirhan'dır. Bilecik merkeze sadece 17 km uzaklıkta ve İstanbul yolu üzerinde kurulmuş olan Vezirhan'da taş ocağı işletmeciliğinin tarihi çok eski dönemlere gitmektedir. Bununla birlikte, özellikle 2000'li yıllardan itibaren eski ocaklar yeniden işletmeye başlamış ve 2003 yılında 246,467 $\mathrm{m}^{2}$ olan maden çıkarım alanlarının yüzölçümü, 2013 yılında 500,442 m²'ye çıkmış, 2016 yılında ise 3 kat artarak 1.594,156 m²'ye ulaşmıştrr. Bu dönemde, Vezirhan'ı yıllara göre sıralaması değişmekle birlikte, Gülümbe, Çukurören, Bayırköy ve Beyce köyleri izlemektedir. 2003 yılında maden çıkarılan alanlar sıralamasında 181,635 m² $^{2}$ yüzölçümü ile ikinci sırada olan Gülümbe köyü 2013 yılında 291,049 m² ile dördüncü sıraya gerilemiștir. Buna karşın, 2003 yılında 178,935 m² yüzölçümü ile üçüncü sırada yer alan Çukurören köyü ise $491.393 \mathrm{~m}^{2}$ yüzölçümü ile ikinci sıraya yükselmiştir. Bu durum, 2003-2013 yılları arasında, Gülümbe'de daha önce açılmış olan 12 noktadaki maden ocağı dışında yeni bir işletmenin açılmamış olmasından kaynaklanmaktadır. Burada yeni ocak açılmamasında ise, 2009 yılında Gülümbe köyü yakınlarında Bilecik Şeyh Edebali Üniversitesi Kampüsü'nün kurulmuş olması ve Porland Porselen Fabrikası'nın yeni tesisler açarak alanını genişletmesi etkili olmuştur. Gülümbe köyündeki işletmelerin sayısı 2013 yılına kadar artş̧ göstermemiş olmakla birlikte, kapladıkları alanın yüzölçümü, 2013-2016 yılları arasında üç katını bulan bir artış göstererek 291,049'dan 916,757 m²’ye çıkmıştır. Buna karşın, Gülümbe'nin hemen yakınındaki Çukurören köyünde ise 2003 yılında 4 noktada bulunan maden ocağı sayısı, 2013 yılında 8'e yükselmiş ve 2016 yılına kadar geçen süreçte ise işletmeler noktasal olarak artmamakla birlikte, alansal olarak hızla genişleyerek $1.284 .032 \mathrm{~m}^{2}$ yüzölçümüne ulaşmıştır.

2013-2016 yılları arasında, Vezirhan, Çukurören ve Gülümbe gibi Bilecik merkez ilçeye çok yakın olan yerleşmelerdeki maden işletmelerinin yüzölçümünde 3-4 kat bir artş̧ olmuştur (Şekil 7). Aynı dönemde, maden çıkarım alanlarının yüzölçümünün hızla arttı̆ı diğer yerler ise İstanbul yolu yakınındaki Bayırköy, Taşçılar, Deresakarı, Selbükü ile Bursa yolu üzerindeki ilyasca, Beyce, Cumalı ve illyasbey köyleridir (Tablo 3). Bu durum, taş ocağı işletmelerinin yer seçiminde, litolojik özelliklerin yanı sıra çevre illerle ulaşım imkanlarının da önemli rolü olduğunu göstermektedir.

Görüldüğü üzere, 2000'li yılların başından itibaren Bilecik merkez ilçedeki taş ocağı işletmeleri hem noktasal olarak artmış hem de alansal olarak hızla büyümüştür. Böylece, işletmelerin açıldığı sahalardaki jeomorfolojik birimler kısa bir süre içerisinde

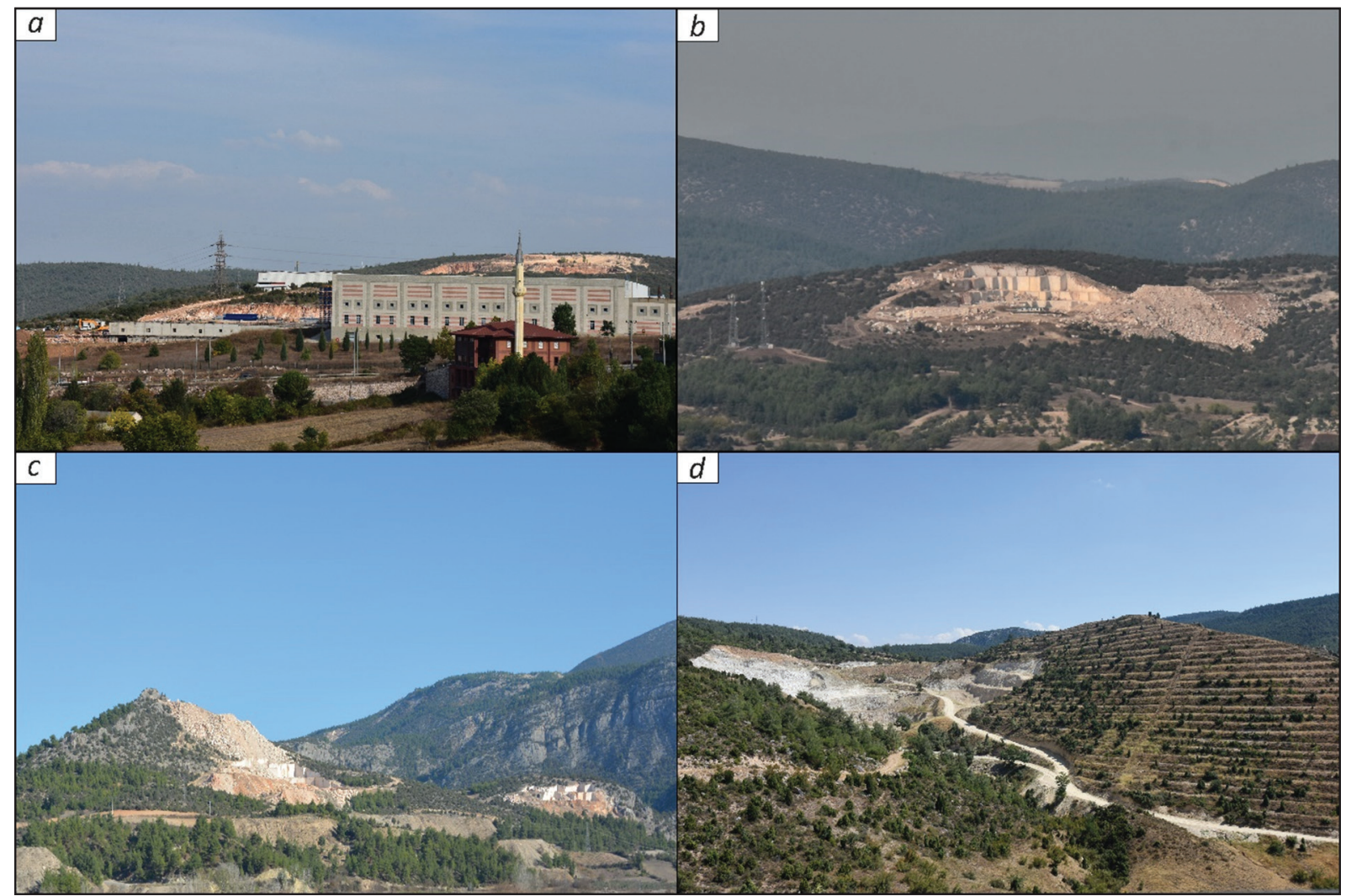

Fotoğraf 1. Porland porselen fabrikası ve gerisindeki Gülümbe taş ocağı (a), Çukurören ve Gemiciköy taş ocağı (b-c) ile Borcak köyü yakınlarında erozyonu kontrol altına almak amacıyla yapılan ağaçlandırmanın içerisinde açılmış olan taş ocağı (d).

Photograph 1. Porland porcelain factory and nearby Gülümbe quarry (a), Quarries Çukurören and Gemiciköy (b-c) and a quarry opened in afforestation near Borcak village in order to control erosion (d). 


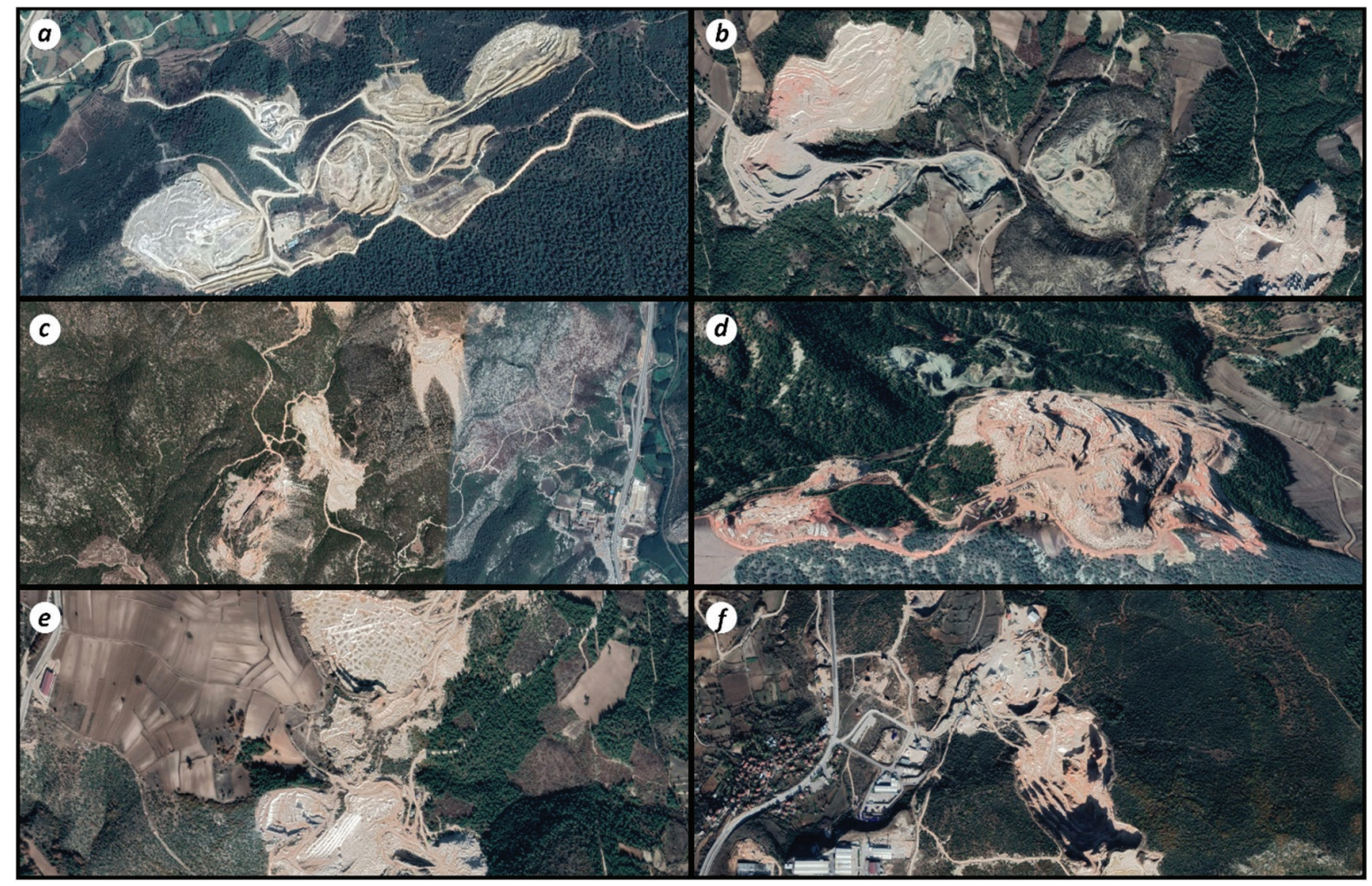

Şekil 5. Google Earth görüntülerinden yüzey madenciliği (a) Bayırköy, (b) Çukurören, (c) Vezirhan, (d) Selbükü, (e) Taşçılar, (f) Gülümbe. Figure 5. Surface mining from Google Earth images (a) Bayırköy, (b) Çukurören, (c) Vezirhan, (d) Selbükü, (e) Taş̧̧lar, (f) Gülümbe.

ya kazılarak tamamen ortadan kaldırılmış ya da tahrip edilerek bırakılmıştır. Bu durumun yerşekilleri üzerinde yarattğı tahribat ve yol açtı̆̆ görüntü kirliliği, köylerdeki taş ocağı işletmelerine ait güncel uydu görüntülerinde açık bir şekilde gözlenmektedir (Fotoğraf 1; Şekil 5). Gülümbe köyündeki işletmelerin zamansal ve mekânsal dağılışındaki değişmeler ise Şekil 6'da verilmiştir.

Bilecik merkez ilçe ve köylerinde yürütülmekte olan antropojenik faaliyetlerin, jeomorfolojik birimler ve süreçler üzerinde etkisini ortaya koyabilmek amacıyla uygulanan Nir (1983)'in "Potansiyel Antropo-jeomorfolojik indeksi" analizine göre çaışma sahasının antropo-jeomorfolojik süreç oranı 0,45 olarak belirlenmiştir. Bu indis değerine göre, Bilecik merkez ilçe, antropojenik tehdit skalasında "orta ölçekte" yer almakta birlikte yüksek değere yakın bir noktada konumlanmaktadır. Buna göre, halen bazı koruma kararları ve önlemleri alınarak antropojenik etkilerin yarattğı tehditlerin kontrol altına alınabilmesi mümkün görünmektedir.
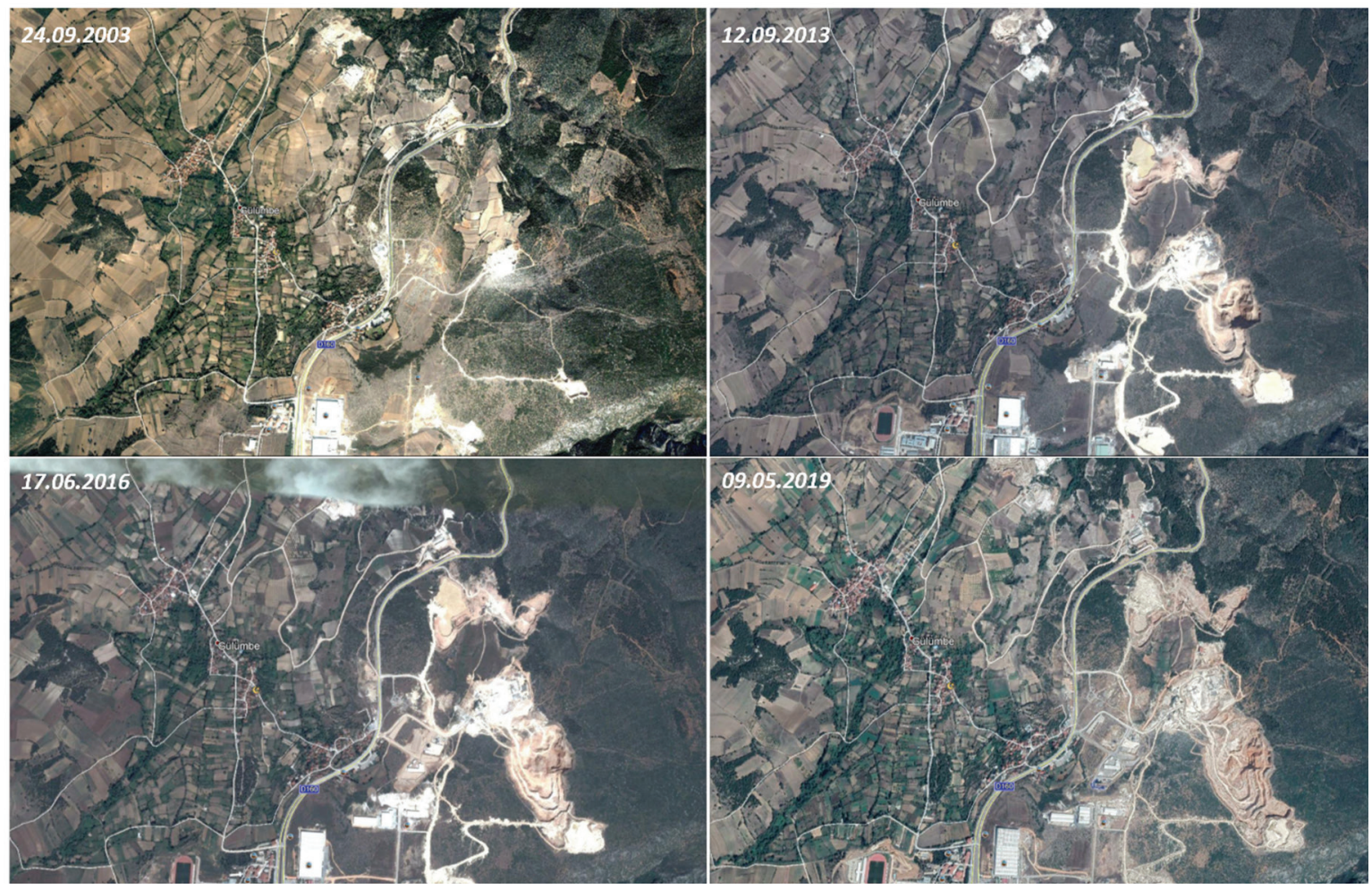

Şekil 6. Gülümbe çevresindeki taş ocaklarının zamansal ve mekânsal değişimi.

Figure 6. Spatiotemporal change of the quarries around Gülümbe. 
Tablo 3. Maden çıkarım alanlarının yıllara göre dağılımı $\left(\mathrm{m}^{2}\right)$.

Table 3. Distribution of mine extraction areas by years $\left(\mathrm{m}^{2}\right)$.

\begin{tabular}{|c|c|c|c|c|c|c|c|}
\hline Yerleşme & 2003 & 2013 & 2016 & Yerleşme & 2003 & 2013 & 2016 \\
\hline Bilecik/Merkez & - & 50.173 & 219.094 & Kurtköy & - & 17.575 & 25.173 \\
\hline Abadiye & - & - & - & Kuyubaşı & & 156.419 & 225.849 \\
\hline Abbaslık & - & - & - & Künceğiz & - & - & - \\
\hline Ahmetpınar & & 1.471 & 3.257 & Küplü & - & - & - \\
\hline Alpağut & 11.219 & 74.543 & 131.916 & Kınık & 4.076 & 54.793 & 148.906 \\
\hline Ayvacık & - & - & - & Kızıldamlar & - & 1.389 & 19.183 \\
\hline Aşağıköy & - & 22.231 & 72.117 & Necmiyeköy & - & 76.828 & 77.403 \\
\hline Bahçecik & - & 22.475 & 22.475 & Okluca & 24.158 & 29.264 & 33.717 \\
\hline Bayırköy & 64.448 & 377.653 & 825.777 & Pelitözü & 11.563 & 95.645 & 129.066 \\
\hline Başköy & - & - & 115.055 & Selbükü & 46.440 & 128.030 & 548.374 \\
\hline Bekdemir & - & - & - & Selöz & - & - & - \\
\hline Beyce & 162.477 & 170.707 & 536.031 & Sütlük & - & - & - \\
\hline Cumalı & 24.363 & 44.521 & 161.356 & Taşçılar & 46.360 & 69.866 & 324.246 \\
\hline Deresakarı & 18.655 & 125.530 & 450.232 & Ulupınar & - & - & - \\
\hline Dereşemsettin & - & 66.497 & 96.721 & Vezirhan & 246.672 & 500.442 & 1.594 .156 \\
\hline Elmabahçe & - & - & - & Yeniköy & 8.048 & 21.604 & 53.323 \\
\hline Erkoca & - & - & - & Çakırpınar & - & - & - \\
\hline Gökpınar & 2.551 & 20.715 & 80.688 & Çavuşköy & - & - & - \\
\hline Gülümbe & 181.635 & 291.049 & 916.757 & Çukurören & 178.935 & 491.393 & 1.284 .032 \\
\hline Hasandere & - & 4.420 & 4.420 & Ören & - & 2.027 & 4.668 \\
\hline Kapaklı & - & - & - & İkizce & - & - & - \\
\hline Karaağaç & - & - & - & İlyasbey & 138.778 & 104.019 & 440.375 \\
\hline Kepirler & - & - & - & \multirow{2}{*}{ Toplam } & \multirow{2}{*}{1.219 .546} & \multirow{2}{*}{3.251 .458} & \multirow{2}{*}{ 8.588.947 } \\
\hline Koyunköy & - & - & - & & & & \\
\hline
\end{tabular}

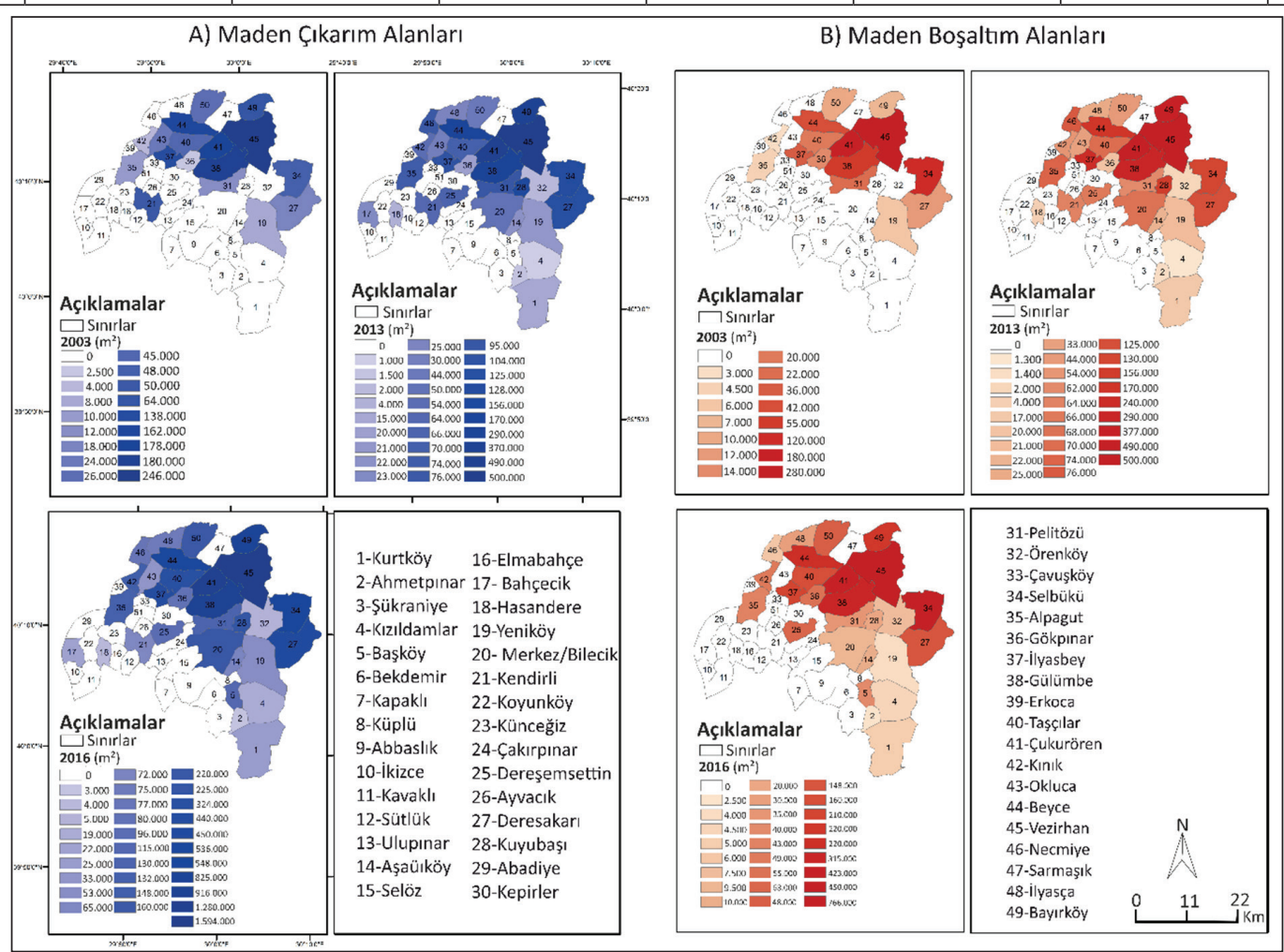

Şekil 7. Çalışma sahası içerisinde yer alan taş ocaklarının zamansal değişimi ve mekânsal dağılışı (A-B). Taş ocaklarının sayısı 2003 yılında 17 köyde, 53 iken 2016 yılında 30 köyde 137'ye; taş ocağı işletme alanı ise 2003 yılında 1.219,549 m² iken 2016 yılında 8.588,947 m²'ye ulaşmıştır.

Figure 7. Temporal change and spatial distribution of the quarries in the study area (A-B). While the number of quarries was 53 in 17 villages in 2003 , it increased to 137 in 30 villages in 2016; the quarry area was 1.219,549 $\mathrm{m}^{2}$ in 2003 and reached 8.588,947 $\mathrm{m}^{2}$ in 2016. 


\section{Sonuç ve Öneriler}

Antroposen çağında, bir yandan hızla artan insan nüfusuna bağlı olarak çeşitlenen ihtiyaçlar diğer yandan da hızlı teknolojik gelişmeler doğal ortam üzerindeki baskının temel nedenini oluşturmaktadır. Bu baskılar, Türkiye gibi sanayileşmenin devam ettiği ve çevre koruma bilincinin yeterince gelişmediği ancak zengin doğal kaynaklara sahip ülkelerde büyük problemler yaşanmasına neden olmaktadır. Kuşkusuz, bu problemlerin yazılı ve görsel basında da en geniş yer bulan kısmını maden ve taş ocakları oluşturmaktadır.

Bilecik ve merkez ilçe örneğinde de ortaya koyulduğu üzere, taş ocakları bir yandan ülke ekonomisi açısından büyük önem taşırken diğer yandan fiziki peyzaj üzerinde yarattğı olumsuz etkilerle milyonlarca yıldan beri süregelen doğal işleyişi hızla değiştirmekte, ekosistemi büyük ölçüde tehdit etmektedir. Bu nedenle, madencilik faaliyetleri ve taş ocağı işletmeciliğinin sürdürülebilir kalkınma çerçevesinde yapılmasına dikkat edilmesi gerekmektedir. Bu işletmelerin yol açtı̆̆ sorunlar ise açılan sahalar ve çıkan atıkların topoğrafyada yarattı̆ı görüntü kirliliği, ocaklardaki patlamalardan kaynaklanan gürültü kirliliği, tozlar nedeniyle hava kalitesinde düşme, yüzey ve yeralt sularında kirlenme, tarım topraklarının kullanılamaz hale gelmesi, doğal bitki örtüsünün tamamen ortadan kaldırılması veya tahrip edilmesi ve biyoçeşitliliğin azalması olarak sıralanabilir. Bütün bu sorunlar, taş ocağı işletmelerinin çevresinde yaşayan halkın yaşam kalitesinin düşürmekte ve ciddi sağlık sorunları yaşamalarına neden olmaktadır. Aslında, ÇED raporları doğrultusunda işletmecilere ruhsat verilirken ortaya çıkabilecek sorunlara karşı gerekli düzenlemeleri yapma zorunluluğu getirilmesi ve resmî kurumların yapacağı işletmelerin ruhsata uygun olarak çalışıp çalışmadıklarına yönelik denetimler sonucunda hem çevre sorunları hem de yerel halkın şikayetleri büyük ölçüde azaltılabilir veya tamamen çözümlenebilir.

Taş ocağı işletmeleri, yatay ve dikey yönde topoğrafyaya vermiş oldukları zarar nedeniyle istilacı bir süreç olarak kabul edilmektedir. Bununla birlikte, "mermer işletmesi" olarak ruhsat verilen taş ocakları, ocaktan çıkartılan taşın kalitelerine bağı olarak farklı şekillerde değerlendirilmektedir. Buna göre, açılan ocaklarda büyük bloklar halinde kesilebilen ve damarlar içermeyen som dokulu kristalize kireçtaşları "mermer ocağı" olarak işletilmekte, kalitesi düşük ve kesilmeye uygun olmayan taşlar ise "mıcır" olarak değerlendirilmektedir. Taş ocağı işletmelerindeki en önemli sorunlardan birisini de ekonomik bakımdan rantabl bulunmayan ocakların, herhangi bir rehabilitasyona tabii tutulmadan kısa sürede terk edilmesi ve yerine başka bir ocak açılması oluşmaktadır. Bu durum, sadece milyonlarca yılda oluşmuş olan yer şekillerini değil koruyucu (toprak ve bitki) örtüsü ortadan kaldırılan yüzeylerdeki erozyon süreçlerini de olumsuz yönde etkilemektedir.

Küreselleşmeye bağlı olarak, ülkemizde birçok maden ocağı uluslararası şirketler tarafindan işletilmektedir. Büyük şirketlerin minimum harcama maksimum kar mantiğıyla işlettiği bu sahalarda işletme sırasında veya kapanma sonrasında birçok çevre problemi yaşanmaktadır. Bunların önüne geçilebilmesi için, uluslararası kuruluşlar tarafindan kabul edilmiş çevreye ve yerel halka daha saygılı bir ortak protokol hazırlanması gerekmektedir. Bilecik'te 2013 yılından itibaren dikkati çeken taş ocaklarının hızlı alansal artş̧ında, Çinli şirketler önemli rol oynamıştır. Bununla birlikte, son yıllarda taş ocaklarının çoğu yerli şirketler tarafindan işletilmeye başlamıştır.

Sonuç olarak, maden ve taş ocaklarının yol açt̆ğı olumsuz etkilerin sürdürülebilir kalkınma çerçevesinde çevresel değerlere uygun koşullara dönüştürülmesi amacıyla dünyada ve ülkemizde çeşitli çalışmalar yapılmaktadır. Bunun için öncelikle, mevcut taş ocaklarının sıkı bir şekilde denetlenmesi ve plansız olarak açılan taş ocaklarının kontrol altına alınması ve/veya kapatılması gerekmektedir. Ayrıca, işlevini tamamlayan taş ocaklarında yasal olarak yapılması gereken iyileştirme (rehabilitasyon) işlemlerinin mutlaka gerçekleştirilmesinin sağlanması ve bu sahaların kamu yararına uygun bir şekilde rekreasyonel amaçlı faaliyetler için değerlendirilmesi yerinde bir karar olacaktır. Bilecik Merkez ilçede yapılacak bu türden bir çalışma, halkın artık şehre neredeyse eklemlenmiş durumda bulunan ve halkın pek sıcak bakmadığı taş ocağı işletmelerine bakış açısında da olumlu bir değişime yol açacaktr. Nitekim, uyguladığımız "Potansiyel Antropo-jeomorfolojik Indeks" değeri, Bilecik'te antropojenik etkilerin yarattğı tehditlerin önemsiz olmadığını ve bazı koruma kararları ile önlemleri uygulanarak kontrol altına alınabileceğini göstermiştir.

\section{Kaynakça}

Bursa-Eskişehir-Bilecik Kalkınma Ajansı (BEBKA). (2017). Bilecik mermer sektörü raporu. BEBKA. https://www.bebka.org.tr/admin/ datas/yayins/149/1496296650.pdf

Crutzen, P. J., \& Stoermer, E. F. (2000). The Anthropocene. Global Change Newsletter, (41), 17-18. http://18.31 6f18321323470177580001401/1376383088452/NL41.pdf

Crutzen, P. J. (2002). Geology of mankind. Nature, (415), pp. 23. https://doi.org/10.1038/415023a

David, L. (2008). Quarrying: An anthropogenic geomorphological approach. Acta Montanistica Slovaca, Rocnik, 13 (1), 66-74. https://www.osti.gov/etdeweb/biblio/21509838

David, L. (2010). Quarrying and other minerals. In Szabo, J., David, L., \& Loczy, D. (Eds.). Anthropogenic geomorphology: A guide to man-made landforms. 113-130, Springer. http://doi. org/10.1007/978-90-481-3058-0

Ellis, E. C., Magliocca, N. R., Stevens, C. J., \& Fuller, D. Q. (2018). Evolving the Anthropocene: Linking multi-level selection with longterm social-ecological change. Sustainability Science, (13), 119128. https://doi.org/10.1007/s11625-017-0513-6

Erkal, T. \& Taş, B. (2013). Jeomorfoloji ve insan, uygulamalı jeomorfoloji. Yeditepe Yayınevi.

Ertek, T. A. (2017). Antropojenik jeomorfoloji: Konusu, kökeni ve amacı. Türk Coğrafya Dergisi, (69), 69-79. http://doi.org/10.17211/ tcd.319409

Golomb, B., \& Eder, H. M. (1964). Landforms made by man. Landscape, (14), 4-7.

Goudie, A. S., \& Viles, H. A. (2016). Geomorphology in the Anthropocene. Cambridge University Press. www.cambridge. org/9781107139961

Harmand, S., Lewis, J. E., Feibel, C. S., Lepre, C. J., Prat, S., Lenoble, A., ... \& Taylor, N. (2015). 3.3-Million-year-old stone tools from Lomekwi 3, West Turkana, Kenya. Nature, 521 (9542), 310-315. https://doi.org/10.1038/nature14464 
Karakoca, E., \& Uncu, L. (2020). Orta Sakarya vadisi akarsu seki sistemlerinin morfometrik ve sedimantolojik özellikleri (İnhisar-Gemiciköy Arası, Bilecik). Coğrafya Dergisi, (41), 165-177. https:// doi.org/10.26650/JGEOG2020-0057

Nir, D. (1983). Man, a geomorphological agent. An introduction to anthropic geomorphology, Keter Publishing House.

Orhan, H., \& Arık, F. (2019). Doğal taşların işletme mevzuatı ve çevre dostu uygulama örnekleri. Mavi Gezegen Popüler Yerbilim Dergisi, (26), 14-25. https://www.jmo.org.tr/yayinlar/dergi goster. php?dergikod=1\&kodu=441\&dergi=MAV\%DD\%20GEZEGEN

Öztürk, M. Z., Çetinkaya, G., \& Aydın, S. (2017). Köppen-Geiger iklim sınıflandırmasına göre Türkiye'nin iklim tipleri. Coğrafya Dergisi, (35), 17-27. https://doi.org/10.26650/JGEOG295515

Rózsa P. (2007). Attempts at qualitative and quantitative assessment of human impact on the landscape. Geografia Fisica e Dinamica Quaternaria, 30 (2), 233-238. http://gfdq.glaciologia.it/volume-30-2-2007/

Sayar, M., \& Erguvanlı, K. (1962). Türkiye mermerleri ve inşaat taşları. İstanbul Teknik Üniversitesi, Maden Fakültesi. İstanbul.

Steffen, W., Crutzen, P. J., \& McNeill, J. R. (2007). The Anthropocene: Are humans now overwhelming the great forces of nature. A Journal of the Human Environment, 36 (8), 614-621. http:// dx.doi.org/10.1579/0044-7447(2007)36[614:TAAHNO]2.0.CO;2

Steffen, W., Grinevald, J., Crutzen, P. J., \& McNeill, J. (2011). The Anthropocene: Conceptual and historical perspectives. Philosophical Transactions of the Royal Society, (369), 842-867. https://doi.org/10.1098/rsta.2010.0327

Steffen, W., Leinfelder, R., Zalasiewicz, J., Waters, C. N., Williams, M., Barnosky, A. D., Cearreta, A., Crutzen, P., Edgeworth, M., Ellis, E. C. (2016). Stratigraphic and Earth system approaches to defining the Anthropocene. Earth's Future, (4), 1-22. https://doi. org/10.1002/2016EF000379

Szabo, J. (2010). Anthropogenic geomorphology: Subject and system. In Szabo, J., David, L., and Loczy, D. (Eds.). Anthropogenic geomorphology: A guide to man-made landforms. 3-10, Springer. http://doi.org/10.1007/978-90-481-3058-0

Tarolli, P., \& Sofia, G. (2016). Human topographic signatures and derived geomorphic processes across landscapes. Geomorphology, (255), 140-161. http://dx.doi.org/10.1016/i.geomorph.2015.12.007

Tarolli, P., Cao, W., Sofia, G., Evans, D., \& Ellis, E. C. (2019). From features to fingerprints: A general diagnostic framework for anthropogenic geomorphology. Progress in Physical Geography, 43 (1), 95-128. https://doi.org/10.1177/0309133318825284

Zalasiewicz, J., Steffen, W., \& Crutzen, P. (2010). The new world of the Anthropocene. Environmental Science \& Technology, (44), 2228-2231. https://doi.org/10.1021/es903118

Zalasiewicz, J., Williams, M., Haywood, A., \& Ellis, M. (2011). The Anthropocene: A new epoch of geological time?. Philosophical Transactions of the Royal Society, (369), 835-841. https://doi. org/10.1098/rsta.2010.0339

Zalasiewicz, J., Waters, C. N., Williams, M., \& Summerhayes, C. P. (Eds.). (2019). The Anthropocene as a geological time unit: $A$ guide to the scientific evidence and current debate. Cambridge University Press. https://doi.org/10.1017/9781108621359 